\title{
Metabotropic Glutamate Receptors Negatively Regulate Melatonin Synthesis in Rat Pinealocytes
}

\author{
Hiroshi Yamada, ${ }^{1}$ Shouki Yatsushiro, ${ }^{1}$ Shougo Ishio, ${ }^{1}$ Mitsuko Hayashi, ${ }^{2}$ Tsuyoshi Nishi, ${ }^{2}$ \\ Akitsugu Yamamoto,, ${ }^{3}$ Masamitsu Futai, ${ }^{2}$ Akihito Yamaguchi, ${ }^{1}$ and Yoshinori Moriyama ${ }^{1}$ \\ Departments of ${ }^{1}$ Cell Membrane Biology and ${ }^{2}$ Molecular Cell Biology, Institute of Scientific and Industrial Research, Osaka \\ University, CREST, Japan Science and Technology Corporation, Ibaraki, Osaka 567, Japan, and ${ }^{3}$ Department of \\ Physiology, Kansai Medical University, Moriguchi, Osaka 570, Japan
}

\begin{abstract}
Rat pinealocytes receive noradrenergic innervation that stimulates melatonin synthesis in a CAMP-mediated manner. In addition to melatonin, we showed previously that pinealocytes secrete L-glutamate through an exocytic mechanism. The released glutamate inhibits norepinephrine (NE)-dependent melatonin synthesis. Consistent with this observation, specific agonists of class II metabotropic glutamate receptors (mGluRs), including 1-(1S,3R)aminocyclopentane-1,3-dicarboxylic acid (tACPD), inhibited NEdependent melatonin synthesis, whereas agonists for other types of glutamate receptors did not. Furthermore, reverse transcriptionPCR, Northern blotting, and immunohistochemistry analyses indicated expression of class II mGluR3 in pinealocytes. Inhibitory
\end{abstract}

guanine nucleotide-binding protein $\left(G_{i}\right)$ was also detected in pinealocytes. L-Glutamate or agonists of class II receptors decreased NE- or forskolin-dependent increase of CAMP and serotonin- $N$-acetyltransferase activities to similar extents. These effects were blocked by pertussis toxin or dibutyryl cAMP. These results indicate that the inhibitory cAMP cascade is involved in the glutamate-evoked inhibition of melatonin synthesis. We propose that the glutaminergic system negatively regulates $\mathrm{NE}$-dependent melatonin synthesis in rat pinealocytes.

Key words: melatonin; pinealocyte; metabotropic glutamate receptor; cAMP cascade; $\mathrm{N}$-acetyltransferase; endocrine cell
Melatonin, a hydrophobic hormone that affects many physiological functions such as circadian rhythm and seasonal reproduction, is mainly synthesized in pinealocytes (Axelrod, 1974; Klein, 1985; Reiter, 1991; Korf et al., 1996). In mammals, the synthesis and discharge of melatonin is under photoperiod control, acting by way of the suprachiasmatic nuclei (SCN) of the hypothalamus (Axelrod, 1974; Klein, 1985; Reiter, 1991; Korf et al., 1996). At night, the SCN send stimulatory signals to the pineal gland through sympathetic neurons. Norepinephrine (NE) released from nerve endings binds to the adrenergic receptors at the plasma membrane of pinealocytes and activates adenylate cyclase through a heterotrimeric guanine nucleotide-binding protein $\left(\mathrm{G}_{\mathrm{s}}\right)$. The resultant increased concentration of cAMP stimulates transcription of serotonin $N$-acetyltransferase (NAT) (Axelrod, 1974; Klein, 1985; Reiter, 1991; Borjigin et al., 1995; Coon et al., 1995; Korf et al., 1996; Roseboom et al., 1996). The daily change of NAT mRNA and its activity are not completely correlated with each other. The rate of decrease of NAT activity is much faster than the rate of degradation of its mRNA in the downregulation phase, which is induced by light exposure (Roseboom et al., 1996; Bernard et al., 1997). This observation suggests the presence of a negative regulatory mechanism for NAT activity in pinealocytes; however, no evidence is available for the functional operation of

Received Oct. 23, 1997; revised Dec. 29, 1997; accepted Dec. 30, 1997.

This work was supported in part by grants from the Japanese Ministry of Education, Science and Culture, the Naito Foundation, and the Takeda Science Foundation. H.Y. and T.N. were supported by Research Fellowships from the Japan Society of the Promotion of Science for Young Scientists. We thank Dr. R. K Nakamoto (University of Virginia) for critical reading of this manuscript.

Correspondence should be addressed to Dr. Yoshinori Moriyama, Department of Cell Membrane Biology, Institute of Scientific and Industrial Research (ISIR), Osaka University, Ibaraki, Osaka 567, Japan.

Copyright (C) 1998 Society for Neuroscience $\quad 0270-6474 / 98 / 182056-07 \$ 05.00 / 0$ such a negative regulatory mechanism in melatonin synthesis in pinealocytes.

Pinealocytes function as glutaminergic endocrine cells and use glutamate as a chemical transmitter through an autocrine- or paracrine-like mechanism. Pinealocytes accumulate L-glutamate in microvesicles and secrete the transmitter by $\mathrm{Ca}^{2+}$-regulated exocytosis (Moriyama and Yamamoto, 1995a,b; Yamada et al., 1996a,b; Yatsushiro et al., 1997). Extracellular glutamate is sequestered through a GLT-1 type $\mathrm{Na}^{+}$-dependent glutamate transporter in the plasma membrane (Yamada et al., 1997). Although the physiological function of glutaminergic systems is not understood at present, this system is a candidate for negative regulation of melatonin synthesis (Moriyama et al., 1996). In fact, exogenous L-glutamate inhibits NAT activity (Govitrapong and Ebadi, 1988) and synthesis (Yamada et al., 1996a,b) and secretion (Kus et al., 1994; van Wyk and Daya, 1994) of melatonin in mammalian pineal glands in vitro. It is likely that this glutamateevoked inhibition of melatonin synthesis is mediated by a signal transduction pathway involving one or more types of glutamate receptors.

To define the role of glutamate in pinealocytes, we investigated a signal transduction pathway by which glutamate inhibits melatonin synthesis in rat pinealocytes. We found that pinealocytes express class II metabotropic glutamate receptors (mGluRs). After binding of agonist, cAMP production is decreased by way of inhibitory G-proteins $\left(\mathrm{G}_{\mathrm{i}}\right)$, resulting in decreased NAT activity and melatonin synthesis. This is the first demonstration of the involvement of mGluRs in the regulation of endocrine function.

\section{MATERIALS AND METHODS}

Cell culture and treatment with glutamate or its analogs. Organ and cell cultures of the pineal glands from Wistar rats at 3 postnatal weeks were performed as described (Yamada et al., 1996a, b; Yatsushiro et al., 1997). 
Table 1. Effects of GluRs agonists on the NE-dependent increase of cAMP and NAT activity

\begin{tabular}{|c|c|c|c|}
\hline Additions & Melatonin production $(\%)$ & NAT activity (\%) & $\begin{array}{l}\text { cAMP synthesis } \\
(\%)\end{array}$ \\
\hline \multicolumn{4}{|l|}{ Experiment 1} \\
\hline Control (+NE $10 \mu \mathrm{M})$ & 100 & 100 & 100 \\
\hline L-Glutamate & $8.2 \pm 2.8$ & $30.6 \pm 6.0$ & $43.8 \pm 3.2$ \\
\hline NMDA & $101.9 \pm 6.1$ & $93.8 \pm 8.4$ & $107.6 \pm 7.8$ \\
\hline AMPA & $102.8 \pm 11.8$ & $100.6 \pm 10.2$ & $98.7 \pm 10.5$ \\
\hline Kainate & $113.0 \pm 8.1$ & $98.4 \pm 7.3$ & $104.6 \pm 9.4$ \\
\hline Ibotenate & $95.6 \pm 7.8$ & $92.6 \pm 6.2$ & $98.0 \pm 6.7$ \\
\hline$(S)-3,5-\mathrm{DHPG}$ & $105.6 \pm 6.8$ & $98.5 \pm 9.2$ & $102.9 \pm 5.6$ \\
\hline Quisqualate & $111.0 \pm 7.4$ & $102.6 \pm 9.5$ & $105.2 \pm 10.4$ \\
\hline tACPD & $56.5 \pm 5.2$ & $46.1 \pm 1.9$ & $52.9 \pm 3.5$ \\
\hline L-CCG-I & $49.1 \pm 3.5$ & $51.6 \pm 1.4$ & $50.0 \pm 1.6$ \\
\hline DCG IV & $57.1 \pm 4.0$ & $55.3 \pm 2.3$ & $48.4 \pm 2.9$ \\
\hline$(S) 4 \mathrm{C} 3 \mathrm{HPG}$ & $62.7 \pm 4.5$ & $60.3 \pm 1.8$ & $55.7 \pm 5.4$ \\
\hline L-AP4 & $108.2 \pm 12.1$ & $101.3 \pm 6.1$ & $103.9 \pm 8.3$ \\
\hline L-Glutamate + MCCG & $69.7 \pm 6.5$ & $95.4 \pm 3.8$ & $101.5 \pm 5.7$ \\
\hline L-CCG-I + MCCG & $101.2 \pm 10.5$ & $106.3 \pm 9.8$ & $104.7 \pm 7.3$ \\
\hline \multicolumn{4}{|l|}{ Experiment 2} \\
\hline Control (+DBcAMP $1 \mathrm{~mm})$ & 100 & 100 & NT \\
\hline $\mathrm{tACPD}$ & $103.5 \pm 2.5$ & $105.5 \pm 4.6$ & NT \\
\hline L-CCG-I & $113.1 \pm 6.9$ & $95.5 \pm 8.2$ & $\mathrm{NT}$ \\
\hline DCG IV & $103.0 \pm 9.1$ & $115.9 \pm 4.2$ & NT \\
\hline
\end{tabular}

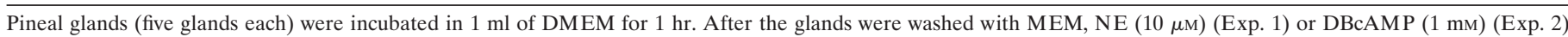

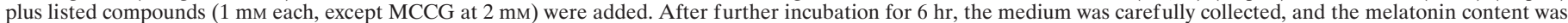

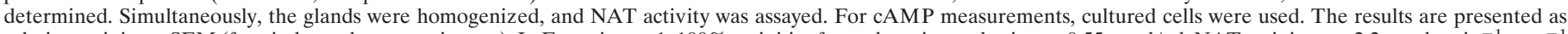

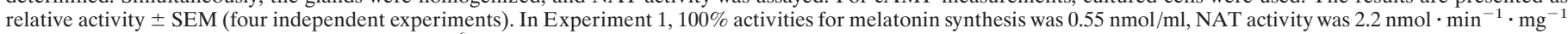

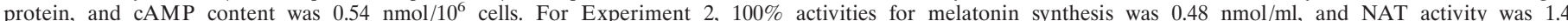

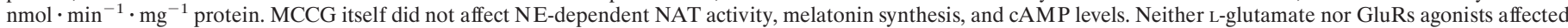

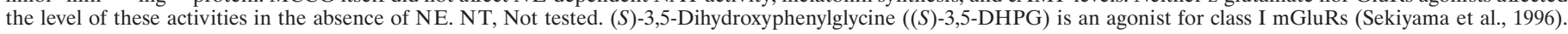

In brief, pineal glands were dissected into small pieces, treated with a $0.1 \%$ collagenase solution (Life Technologies, Gaithersburg, MD) at $37^{\circ} \mathrm{C}$ for $30 \mathrm{~min}$ with gentle shaking, and washed with PBS. After centrif ugation at $180 \times g$ for $2 \mathrm{~min}$, the pieces were treated with $0.025 \%$ trypsin solution (Life Technologies) at $37^{\circ} \mathrm{C}$ for $20 \mathrm{~min}$ and centrifuged at $180 \times \mathrm{g}$ for $5 \mathrm{~min}$. The dispersed cells were washed three times with DMEM supplemented with $6 \%$ fetal calf serum, $55 \mu \mathrm{g} / \mathrm{ml}$ sodium pyruvate, $6 \mathrm{mg} / \mathrm{ml}$ glucose, $0.1 \mathrm{mg} / 1$ streptomycin, $100 \mathrm{U} / \mathrm{ml}$ penicillin $\mathrm{G}$, and $0.25 \mathrm{mg} / \mathrm{l}$ fungizone. Cells were placed in a $35 \mathrm{~mm}$ culture dish coated with collagen (type I) (Corning, Corning, NY) to give $2.5 \times 10^{6}$ cells/ dish, and they were cultured in the above medium at $37^{\circ} \mathrm{C}$ under $10 \%$ $\mathrm{CO}_{2}$. For experimental procedures, organ and cell cultures were maintained for 1 and $5 \mathrm{~d}$, respectively, washed with culture media, and cultured further for $1 \mathrm{hr}$. At this point, $10 \mu \mathrm{M} \mathrm{NE}$ and glutamate or its analogs at the indicated concentrations were included. After further incubation for $6 \mathrm{hr}$, media and cells were carefully collected and used for experiments.

Reverse transcription-PCR (RT-PCR) analysis. Total RNA extracted from isolated glands $(1 \mu \mathrm{g})$ was transcribed into cDNA in a final volume of $20 \mu \mathrm{l}$ of reaction buffer containing $0.5 \mathrm{~mm}$ each deoxynucleotide triphosphate (dNTP), $10 \mathrm{~mm}$ dithiothreitol, $100 \mathrm{pmol}$ of random octamers, and $200 \mathrm{U}$ Moloney murine leukemia virus reverse transcriptase (Amersham, Japan, Tokyo, Japan). After a $1 \mathrm{hr}$ incubation at $42^{\circ} \mathrm{C}$, the reaction was terminated by heating at $90^{\circ} \mathrm{C}$ for $5 \mathrm{~min}$. For PCR amplification, the 100-fold diluted synthesized cDNA solution was added to the reaction buffer containing $0.12 \mathrm{mM}$ dNTPs ( $30 \mu \mathrm{M}$ each dNTPs), $25 \mathrm{pmol}$ of primers, and $1.5 \mathrm{U}$ recombinant Taq DNA polymerase (Takara). Thirty temperature cycles were conducted as follows: denaturation at $94^{\circ} \mathrm{C}$ for $30 \mathrm{sec}$, annealing at temperatures specific for each set of primers for $30 \mathrm{sec}$, and extension at $72^{\circ} \mathrm{C}$ for $1 \mathrm{~min}$. Then the resultant products were diluted 100-fold, and the solution $(1 \mu \mathrm{l})$ was transferred into the nested PCR buffer containing $60 \mu \mathrm{M}$ dNTPs ( $15 \mu \mathrm{M}$ each), $25 \mathrm{pmol}$ of primers, and $1.5 \mathrm{U} \mathrm{Taq}$ polymerase. Then, 25 temperature cycles were conducted as described above. Amplification products were finally analyzed by PAGE.

Sequences of the oligonucleotides used as primers were based on published sequences (Tanabe et al., 1992). The following sequences were used for amplification of mGluR2: the specific sense primer, 5'CCAC TCTCTGCGGGCCGTGCC-3' (bases 1091-1112); the antisense primer, 5'-CCTATCTGCGGGCAGGCAGTGGG-3' (bases 1369-1391); primer for the second PCR, 5'-GGTTAATGCCGTCTATGCCATG-3' (bases 1143-1164); and the antisense primer, 5'CTTTGGTGACGGTATTGGCCGC-5' (bases 1335-1356). The following sequences were used for amplification of mGluR3: the specific sense primer, 5'-GCTCCAACATCCGCAAGTCCTA-3' (bases 746-767); the antisense primer, 5'-GACAAGCACCTGGCCATTGACA-3' (bases 1120-1141); the sense primer for the second PCR, 5'-CCTACGACAGCGTGATACGTGA-3' (bases 764-786); and the antisense primer, 5'TGATCGCTACTTCCAGAGCCTC-3' (bases 999-1020).

Northern blotting. Total RNA $(25 \mu \mathrm{g})$ isolated from pineal gland or other tissues was separated on a formaldehyde agarose gel (1\%) and transferred to a nylon membrane (Amersham). The immobilized RNA was probed with cDNA fragments of mGluR2 and mGluR3 (bases 1143-1356 and $764-1020$, respectively) labeled with $\left[{ }^{32} \mathrm{P}\right] \mathrm{dCTP}$ by random priming. After they were washed extensively, the membranes were subjected to autoradiography using BAS 1000 film (Fuji Film Co.).

Immunohistochemistry. Pineal cells on poly-L-lysine-coated glass coverslips were fixed in $4 \%$ paraformaldehyde for $20 \mathrm{~min}$, washed with PBS, incubated with PBS containing $0.1 \%$ Triton X-100 for 30 min and further with $10 \%$ goat serum in PBS, and reacted with antibodies at $5 \mu \mathrm{g} / \mathrm{ml}$ and antisera at $200 \times$ diluted in PBS containing $0.5 \%$ bovine serum albumin for $1 \mathrm{hr}$. The samples were washed three times with PBS and reacted with the second antibodies conjugated with rhodamine (red) or fluorescein (green), and the immunoreactivity was observed under an Olympus $\mathrm{BH}-2$ fluorescence microscope.

ADP-ribosylation of $G_{i}$ protein. Pertussis toxin (PTX) holoenzyme was activated with $0.1 \mathrm{M}$ Tris- $\mathrm{HCl}, \mathrm{pH} 8.0$, containing $0.1 \mathrm{M}$ dithiothreitol and $0.1 \mathrm{mM}$ ATP at $30^{\circ} \mathrm{C}$ for $30 \mathrm{~min}$. Pinealocytes $\left(1.25 \times 10^{7} \mathrm{cells} / \mathrm{dish}\right)$ were cultured in the presence or absence of PTX $(0.1$ or $1 \mu \mathrm{g} / \mathrm{ml})$ for $24 \mathrm{hr}$. The cells were homogenized in $50 \mathrm{~mm}$ Tris- $\mathrm{HCl}, \mathrm{pH} 8.0$, containing 5 $\mu \mathrm{g} / \mathrm{ml}$ leupeptin and $5 \mu \mathrm{g} / \mathrm{ml}$ pepstatin $\mathrm{A}$ at $4^{\circ} \mathrm{C}$ and centrifuged at $1000 \times g$ for $10 \mathrm{~min}$. The resultant supernatant was further centrifuged 
A

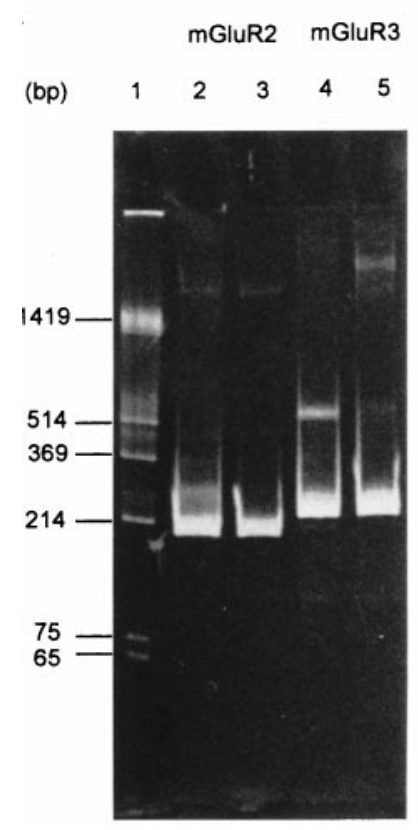

B

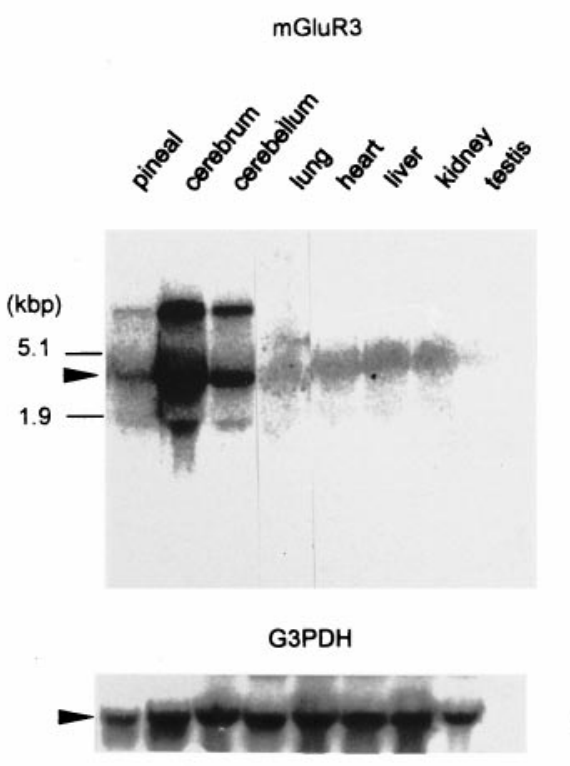

C

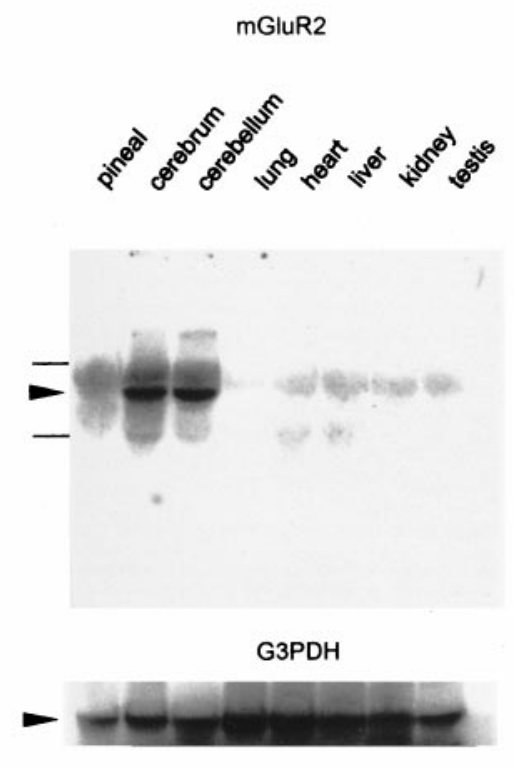

Figure 1. Expression of mGluR3 in pineal glands. A, RT-PCR detection of transcripts for mGluR2 (lanes 2 and 3; expected product size was 214 bp) and mGluR3 (lanes 4 and 5; expected product size was $257 \mathrm{bp}$ ) in pineal gland (lanes 3 and 5) and brain (lanes 2 and 4 ). Molecular weight markers are in lane 1. B, C Expression in various tissues of mGluR3 mRNA $(B)$ and mGluR2 mRNA $(C)$ was examined by Northern analysis. Total RNA from the indicated tissue sources were probed as described in Materials and Methods. For a loading control, hybridization of probes specific for G3PDH transcripts was performed in the same RNA blots as shown in the bottom panel.

at $96,000 \times g$ for $30 \mathrm{~min}$. The pellet was suspended in $0.1 \mathrm{M}$ Tris- $\mathrm{HCl}$, $\mathrm{pH}$ 8.0 , and used as the membrane fraction from pinealocytes. The membranes (30 $\mu \mathrm{g}$ protein) were labeled with [ $\left.{ }^{32} \mathrm{P}\right] \mathrm{NAD}(67 \mu \mathrm{M}, 2 \mu \mathrm{Ci} / \mathrm{assay})$ in the presence of PTX $(10 \mu \mathrm{g} / \mathrm{ml})$ in a buffer consisting of $0.1 \mathrm{M}$ Tris-Cl, $\mathrm{pH}$ 8.0, $10 \mathrm{~mm}$ thymidine, $1 \mathrm{~mm}$ ATP, $0.1 \mathrm{~mm}$ GTP, $0.1 \mathrm{mM} \mathrm{MgCl}_{2}, 1 \mathrm{~mm}$ EDTA, and $1 \mathrm{~mm}$ dithiothreitol at $30^{\circ} \mathrm{C}$ for $30 \mathrm{~min}$ (Bokoch et al., 1983). The assays were terminated by addition of SDS sample buffer, and the proteins were separated on a $10 \%$ polyacrylamide gel in the presence of SDS. Labeled protein bands were visualized with BAS $1000 \mathrm{film}$.

Quantitation of cAMP. Cells $\left(2.5 \times 10^{6}\right.$ cells/dish $)$ were washed twice with Ringer's solution, incubated with $1 \mathrm{~mm} 3$-isobutyl-1-methylxanthine for $20 \mathrm{~min}$, and exposed for $10 \mathrm{~min}$ at $37^{\circ} \mathrm{C}$ to various concentrations of glutamate or its analogs in the presence or absence of $10 \mu \mathrm{M} \mathrm{NE}$ (Tanabe et al., 1992). The reactions were terminated by washing cells with ice-cold Ringer's solution containing 5\% trichloroacetic acid. The cells were then vigorously homogenized and centrifuged at $1500 \times g$ for $10 \mathrm{~min}$. After centrifugation, the supernatant was carefully collected, and the content of cAMP was measured by enzyme immunoassay according to the manufacturer's instructions (Amersham).

Other procedures. Melatonin was measured by HPLC using an IRICA RP-18T column and an amperometric detector (E-558) as described by Sagara et al. (1988). NAT activity was measured as described previously (Thomas et al., 1990). DNA sequencing was performed by the chaintermination method (Sambrook et al., 1989). Membrane fractions from rat brain were prepared as in Moriyama and Futai (1990). Protein concentrations were determined using a Bio-Rad Protein Assay Kit with bovine serum albumin as a standard.

Materials. Agonists and antagonists for GluRs listed in Table 1 were purchased from Tocris Cookson. $\left.{ }^{32} \mathrm{P}\right] \mathrm{NAD}(30 \mathrm{Ci} / \mathrm{mmol})$ was obtained from New England Nuclear. PTX was from Research Biochemicals (Natick, MA). The cAMP enzyme immunoassay kit was from Amersham. Polyclonal antibodies against mGluR $2 / 3$ and monoclonal antibodies against $\mathrm{G}_{\mathrm{i}} 1-\alpha$ proteins were obtained from Chemicon (Temecula, CA). Polyclonal antibodies against $\mathrm{G}_{\mathrm{i}} 1-\alpha$ proteins were also obtained from Wako Chemicals (Osaka, Japan). Monoclonal antibodies against synaptophysin (mAb171B5) (Obata et al., 1986) were kindly supplied by Dr. M. Takahashi (Mitsubishi Kagaku Institute of Life Science, Japan). Other chemicals used in the study were the highest grade commercially available.

\section{RESULTS}

\section{Effects of GluR agonists on NE-stimulated melatonin synthesis}

Exogenous L-glutamate strongly inhibited both NE-stimulated melatonin synthesis and NAT activity (Table 1). The inhibition was not observed with D-glutamate or its metabolites such as $\gamma$-aminobutyrate (Yamada et al., 1996a), supporting the conclusion that receptor-mediated glutamate signaling is involved in the inhibition. Pharmacological analyses with agonists for various GluRs were performed to investigate participation of GluRs in this putative glutamate signaling in pinealocytes. We observed that $1 \mathrm{~mm}$ tACPD, (2S,1'S,2'S)-2-(carboxycyclopropyl)-glycine (L-CCG-I), (2S, $\left.2^{\prime} \mathrm{R}, 3^{\prime} \mathrm{R}\right)-2-\left(2^{\prime}, 3^{\prime}\right)$ dicarboxycyclopropyl-glycine (DCGIV), and ( $S)$-4-carboxy-3-hydroxyphenylglycine [ $(S) 4 \mathrm{C} 3 \mathrm{HPG}]$, agonists for class II mGluRs (Hayashi et al., 1992, 1993, 1994; Tanabe et al., 1992 , 1993), inhibited melatonin synthesis $\sim 50 \%$, as was the case of L-glutamate. No other mGluR agonists, including NMDA and quisqualate, were effective (Table 1). Furthermore, the glutamateor L-CCG-I-evoked action was blocked by (2S,3S,4S)-2-methyl-2(carboxycyclopropyl)glycine (MCCG), a specific antagonist for class II mGluRs (Sekiyama et al., 1996) (Table 1). These results strongly suggest that class II mGluRs are involved in glutamate signaling. Because this class of mGluRs is known to be negatively coupled to adenylate cyclase (Nakanishi, 1992; Tanabe et al., 1992, 1993; Riedel, 1996), we hypothesized that on binding of glutamate, the receptor triggers a $G_{i}$ cascade resulting in decreased cAMP concentration and, subsequently, decreased NAT activity and melatonin synthesis. 

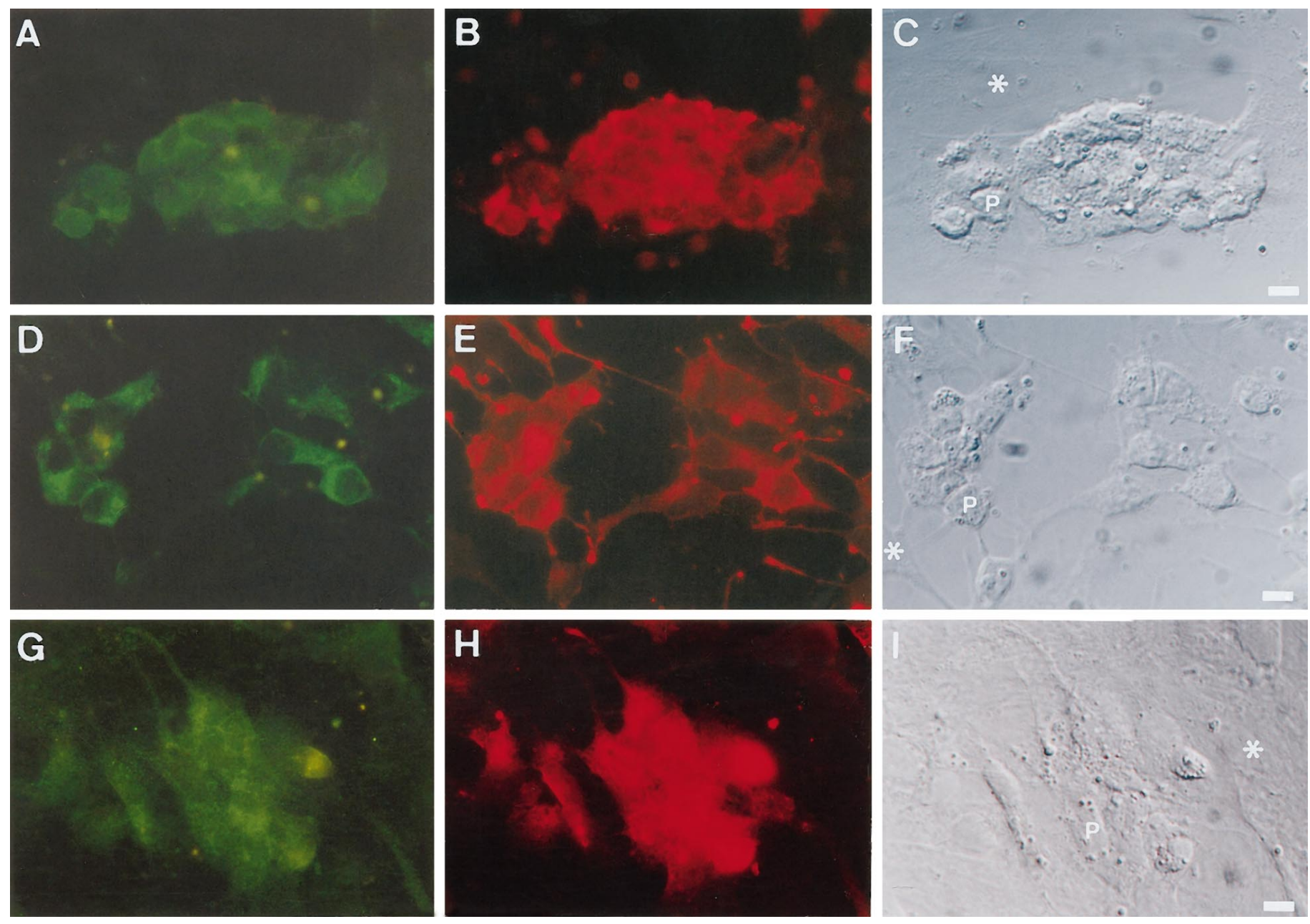

Figure 2. Immunohistochemical localization of mGluR3 and $\mathrm{G}_{\mathrm{i}}$ in pinealocytes. Cultured pineal cells were double-immunolabeled with antibodies against both mGluR2/3 and synaptophysin $(A, B)$, or $\mathrm{G}_{\mathrm{i}} 1 \alpha$ and synaptophysin $(D, E)$. Colocalization of $\mathrm{mGluR}(G)$ and $\mathrm{G}_{\mathrm{i}} 1 \alpha(H)$ in the same pinealocytes was also shown by immunostaining with antibodies against mGluR2/3 and monoclonal antibodies against $\mathrm{G}_{\mathrm{i}} 1 \alpha$. Nomarski images of each cell are shown $(C, F, I)$ * indicates nonpinealocytes, which includes glial cells. $P$, Pinealocyte. Scale bar, $10 \mu \mathrm{m}$.

\section{Expression of mGluR3 in pineal gland}

To test this hypothesis, we investigated whether class II mGluRs are expressed in pineal glands. There are two known isoforms of class II mGluRs: mGluR2 and mGluR3 (Nakanishi, 1992; Tanabe et al., 1992, 1993; Riedel, 1996). In RT-PCR analysis of pineal RNA, amplified products of the expected sizes were obtained (Fig. 1A). The nucleotide and deduced amino acid sequences of the amplified DNA products exactly matched those of the two isoforms. Northern analysis using the RT-PCR products further demonstrated the expression of mRNA for mGluR3 (Fig. 1B). Two distinct RNA bands from brain and pineal origins hybridized with the mGluR3 probe. The presence in brain of two distinct RNA bands for this receptor was reported previously (Tanabe et al., 1993). Furthermore, no expression of the mRNAs for mGluR3 was observed in other tissues tested (Fig. 1B). On the other hand, there was no detectable hybridization of the mGluR2 probe to pineal gland RNA (Fig. 1C). It appears that the level of mGluR2 transcript was below the detection limit of our Northern analysis.

\section{Localization of mGluR3 and $G_{i}$ in pinealocytes}

Because the pineal gland contains several cell types, localization of mGluR3 to pinealocytes was important. Immunohistochemis- try with antibodies specific for class II mGluRs indicated that the antigen was expressed in synaptophysin-positive cells, an indicator of pinealocytes (Redecker and Bargsten, 1993; Moriyama and Yamamoto, 1995a; Yamada et al., 1996a). No antigen was present in nonpinealocyte cells (Fig. $2 A-C$ ). $\mathrm{G}_{\mathrm{i}} 1 \alpha$, the major subunit of the $G_{i}$ protein that is linked to mGluR3, was also detected immunologically in pinealocytes but not in other cells types (Fig. $2 D-F)$. Both class II mGluRs and $\mathrm{G}_{\mathrm{i}}$ proteins were colocalized in the same pinealocytes (Fig. 2G-I). These results confirmed that both mGluR3 and $G_{i}$ proteins are present in pinealocytes.

\section{Mechanism of glutamate-evoked inhibition of melatonin synthesis}

We further investigated the glutamate-mediated signaling pathway that inhibits melatonin synthesis. As expected, L-glutamate and four different mGluR3 agonists [tACPD, L-CCG-I, DCGIV, and $(S) 4 \mathrm{C} 3 \mathrm{HPG}]$ decreased both cAMP and NAT activity in a parallel manner (Table 1). These effects were reversible. After cells were washed to remove agonists, the concentration of cAMP, NAT activity, and melatonin synthesis returned to control levels after addition of NE. Similar glutamate- or agonistevoked inhibition of cAMP synthesis was observed with cells stimulated by isoprenaline, a specific agonist for $\beta$ receptors 


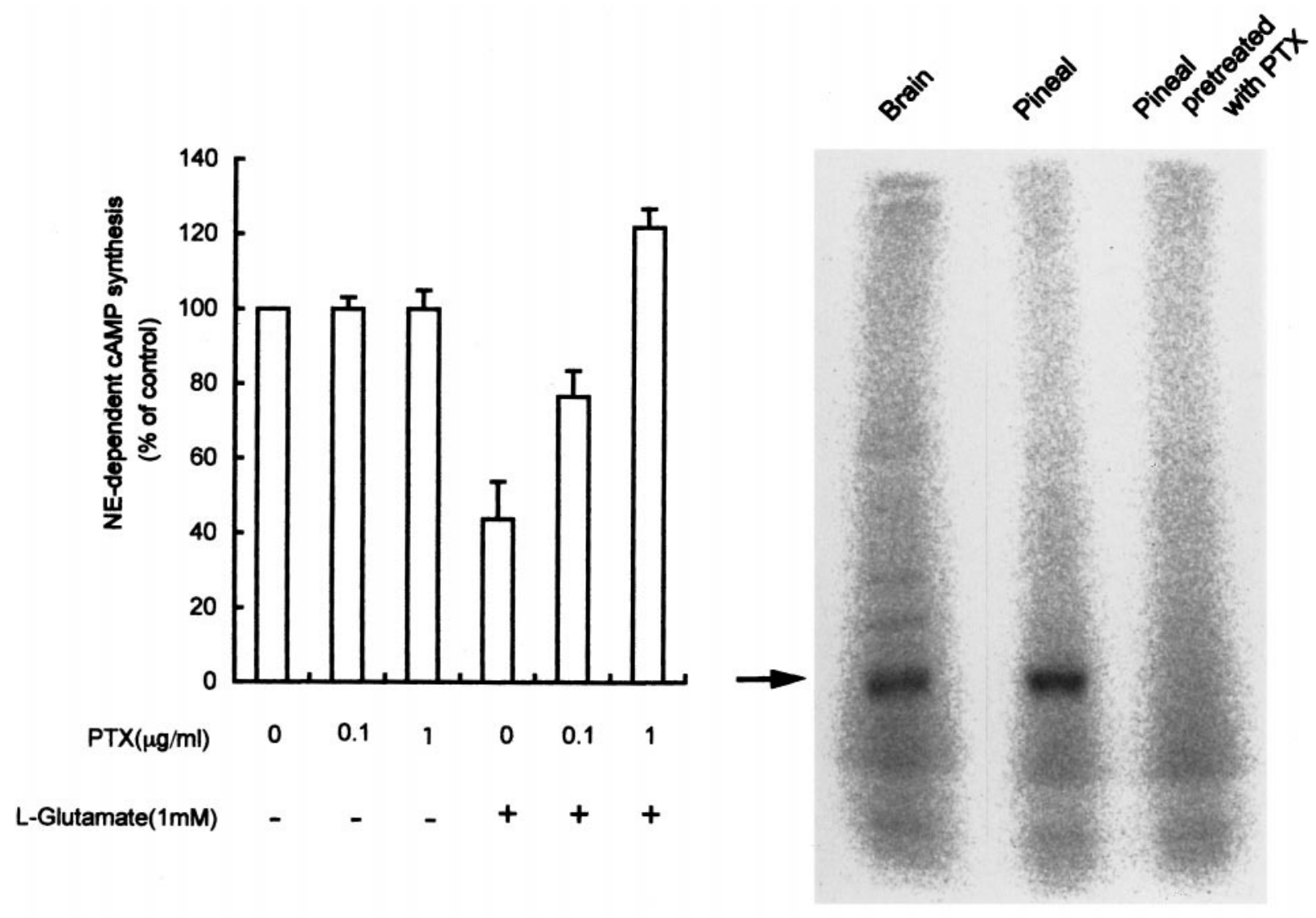

Figure 3. A, B, PTX blocks glutamate-evoked decrease of cAMP. A, Pinealocytes were treated with PTX in the presence or absence of 1 mM glutamate, and cAMP content was measured as described in Materials and Methods. Data are the mean \pm SEM of five independent experiments (bars). Control activity $(100 \%)$ was $0.54 \mathrm{nmol} / 10^{6}$ cells. $B,\left[{ }^{32} \mathrm{P}\right] \mathrm{ADP}$-ribosylation of membranes from brain cortex and cultured pineal cells was performed as described in Materials and Methods. Proteins were separated by SDS-PAGE and visualized by autoradiography. In the right lane, pineal membranes were pretreated with PTX to block ribosylation sites. The arrow indicates Gi1 $\alpha$.

(Rosen et al., 1970), or forskolin, a direct activator of adenylate cyclase (Henquin et al., 1983) (data not shown). These results suggested that the target of glutamate and agonists of pineal mGluR3 is adenylate cyclase or downstream of it in noradrenergic signaling.

To obtain convincing evidence for functional coupling between mGluR3 and adenylate cyclase, the effect of dibutyryl cAMP (DBcAMP), a nonhydrolyzable cAMP analog, and PTX, a specific uncoupler of adenylate cyclase and $G_{i}$, was investigated. Both treatments were expected to eliminate agonist-evoked decrease of cAMP concentration and NAT activity. Addition of DBcAMP restored NAT activity and melatonin synthesis, both of which were inhibited by L-glutamate and mGluR3 agonists (Table 1). PTX also blocked the glutamate-dependent decrease of cAMP (Fig. 3A). Furthermore, under these conditions, PTX was found to block ADP-ribosylation of $\mathrm{G}_{\mathrm{i}} \alpha$ (Fig. $3 B$ ). On the basis of these results, we concluded that mGluR3 and adenylate cyclase are coupled through $G_{i}$ in pineal glands.

\section{DISCUSSION}

L-Glutamate is an excitatory neurotransmitter of the CNS (Foster and Fagg, 1984; Mayer and Westbrook, 1987). Recently, relatively high concentrations of glutamate and the fundamental elements of glutaminergic systems have been detected in peripheral endocrine organs such as islets of Langerhans (Inagaki et al., 1995; Weaver et al., 1996), posterior pituitary (Meeker et al., 1994), and pineal gland (Moriyama et al., 1996). Although the peripheral glutaminergic systems were thought to be responsible for regulation of hormonal secretion, little is known about their precise roles or their modes of action. Mammalian pineal glands provide good experimental systems for investigations of the function of the peripheral glutaminergic systems, because parenchymal pinealocytes contain the complete machinery for secretion, termination, and utilization of glutamate signals (Moriyama et al., 1996). In this study we investigated the mechanism by which glutamate inhibits NE-dependent melatonin synthesis. We found that class II glutamate receptors are negatively coupled to adenylate cyclase through $\mathrm{G}_{\mathrm{i}}$.

Involvement of mGluR3 (or a closely related homolog previously unidentified) in glutamate-evoked inhibition of melatonin synthesis was made evident by the following observations: (1) agonists for class II mGluRs showed effects similar to Lglutamate; (2) an antagonist for class II mGluRs blocked glutamate- and L-CCG-I-evoked inhibition of melatonin synthesis; (3) mGluR3 is expressed predominantly in pinealocytes; (4) mGluR3 is functionally coupled as indicated by the $\mathrm{G}_{\mathrm{i}}$-dependent decrease in cAMP levels on exposure to glutamate or mGluR agonists; and (5) glutamate inhibits NAT activity in parallel to lowered cAMP. Figure 4 depicts a model of the glutaminergic signaling cascade in pinealocytes. Noradrenergic stimulation from sympathetic neurons stimulates melatonin synthesis in a 


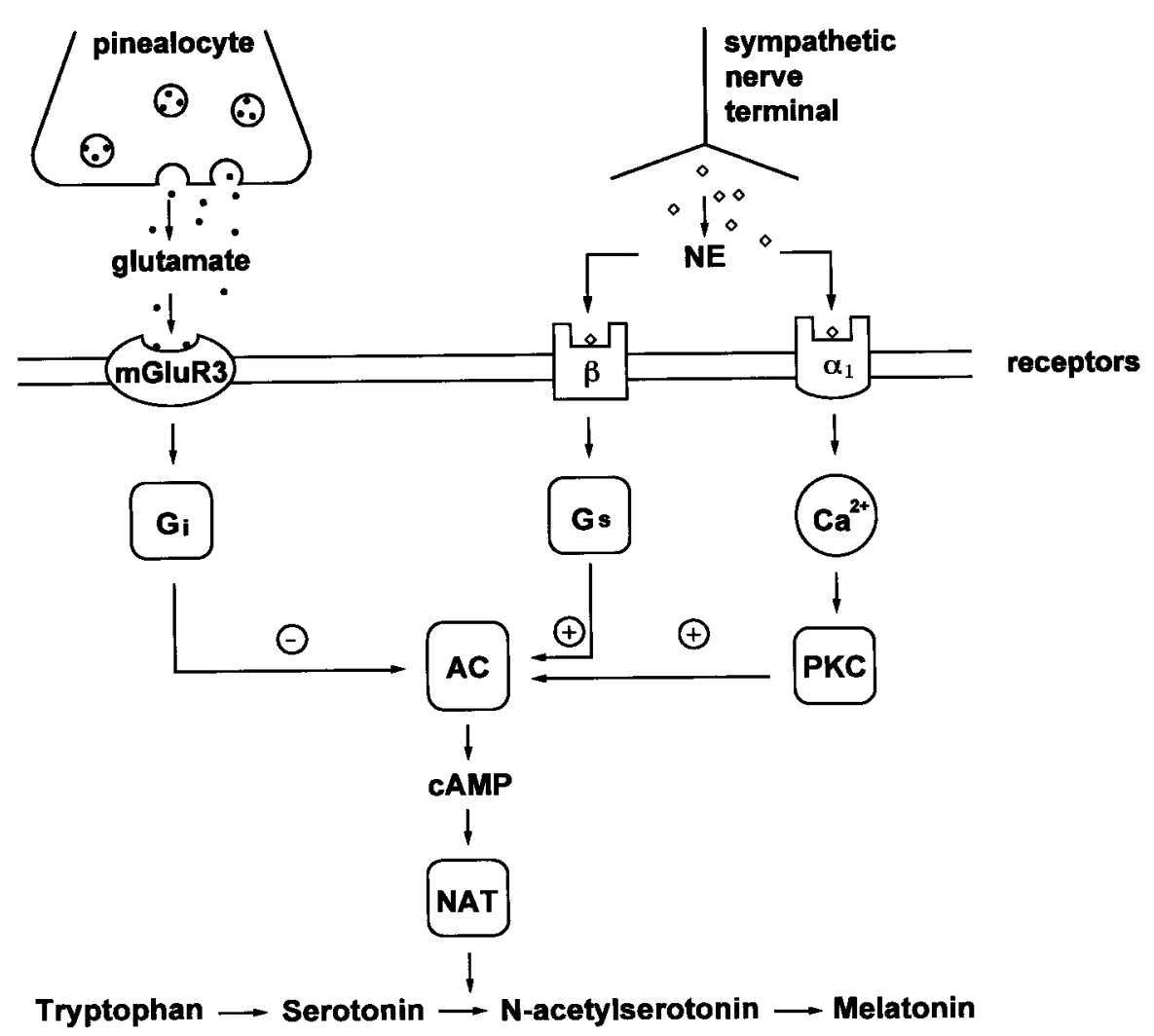

Figure 4. Proposed pathway for L-glutamatemediated inhibition of NE-dependent melatonin synthesis in pinealocytes. NE comes from a sympathetic nerve terminal through a neurocrine mechanism, whereas L-glutamate comes from neighboring pinealocytes through a paracrine-like mechanism. $A C$, Adenylate cyclase; PKC, C kinase; + , stimulatory; - , inhibitory.
cAMP-mediated manner. Glutamate signals through paracrineor autocrine-like mechanisms from pinealocytes stimulate pinealocytes via mGluR3. This results in a block of the noradrenergic cascade by decreasing cAMP levels.

In addition to class II mGluRs, the class III receptors, mGluR4, $-6,-7$, and -8 , are also known to induce inhibitory cAMP-mediated cascades (Nakanishi, 1992; Tanabe et al., 1992, 1993; Thomsen et al., 1992; Okamoto et al., 1994; Riedel, 1996); however, combined RT-PCR and Northern blotting with specific probes for these receptors indicated that only the mGluR7 transcript was present in pineal glands (S. Yatsushiro, Y. Yamada, Y. Moriyama, unpublished observation). We note that the mRNA level was below the detection limit, similar to the case of mGluR2. Furthermore, L-2amino-4-phosphonobutyrate (L-AP4), an agonist for mGluR7 (Thomsen et al., 1992; Okamoto et al., 1994), does not inhibit melatonin synthesis. Taken together, these results suggest that class III mGluRs do not participate in the inhibition of melatonin synthesis. The possibility that closely related homologs of class II mGluRs or novel types of receptors are involved in the signaling cannot be completely excluded at this time.

We point out that the glutamate-evoked signaling via mGluR3 almost completely inhibited melatonin synthesis, whereas under the same conditions $\sim 40 \%$ of NE-dependent NAT activity and cAMP levels remained (Table 1). Agonists for mGluR3 inhibited $\sim 50 \%$ of melatonin synthesis, NAT activity, and cAMP levels (Table 1). MCCG completely blocked the action of the agonists, whereas the compound partially blocked the glutamate-evoked inhibition of melatonin synthesis (Table 1). These results suggested the presence of alternative inhibitory pathways for melatonin synthesis other than the mGluR-mediated signaling cascade demonstrated here. Preliminary experiments suggest that the target of the alternative pathway is located in the melatonin-producing pathway downstream of NAT (S. Ishio, Y. Yamada, Y. Moriyama, unpub- lished data). It is also possible that the simultaneous activation of GluRs other than class II mGluRs, which are not effective when stimulated alone, may contribute to the glutamate action. In any event, glutamate-evoked inhibition of melatonin synthesis is observed in the presence of $\mathrm{NE}$, indicating that the glutamate signal dominates noradrenergic control. It is likely that the glutaminergic system functions as an autonomic regulatory mechanism against neuronal control in the pineal gland.

In vivo, secretion of $\mathrm{NE}$ from sympathetic nerve terminals determines circadian rhythmicity of melatonin synthesis by way of NAT activity. The systems generating the melatonin rhythm in chickens and presumably other avians is believed to be different in mammals, because the chicken pineal gland is directly photosensitive and the rhythm emanates from the pineal gland itself (Axelrod, 1974; Klein, 1985; Reiter, 1991; Korf et al., 1996). Furthermore, NE from chicken sympathetic neurons is released in daytime and inhibits melatonin output through an $\alpha \mathrm{II}$ receptor-linked inhibitory cAMP cascade (Pratt and Takahashi, 1987; Zatz and Mullen, 1988). The glutaminergic signaling cascade found in rat pinealocytes may functionally replace the $\mathrm{NE}$ signaling in chick pineal glands. We further point out the similarity in the neuroendocrine properties of pinealocytes and retinal photoreceptor cells. Both cells are derived from hypothalamus, secrete glutamate by regulated exocytosis, and sequester it through a $\mathrm{Na}^{+}$-dependent glutamate transporter. In addition, the photoreceptor cells may synthesize and secrete melatonin with circadian rhythmicity (Tosini and Menaker, 1996). We expect that glutaminergic systems similarly regulate melatonin synthesis in photoreceptor cells.

\section{REFERENCES}

Axelrod J (1974) The pineal gland: a neurochemical transducer. Science 184:1341-1348. 
Bernard M, Klein DC, Zatz M (1997) Chick pineal clock regulates serotonin $N$-acetyltransferase mRNA rhythm in culture. Proc Natl Acad Sci USA 94:304-309.

Bokoch GM, Katada T, Northup JK, Hewlett EL, Gilman AG (1983) Identification of the predominant substrate for ADP-ribosylation by islet activating protein. J Biol Chem 258:2072-2075.

Borjigin J, Wang MM, Snyder SH (1995) Diurnal variation in mRNA encoding serotonin $N$-acetyltransferase in pineal gland. Nature 378:783-785.

Coon SL, Roseboom PH, Baler R, Weller JL, Namboodiri MAA, Koonin EV, Klein DC (1995) Pineal serotonin $N$-acetyltransferase: expression cloning and molecular analysis. Science 270:1681-1683.

Foster A, Fagg G (1984) Acidic amino acids binding sites in mammalian neuronal membranes: their characteristics and relationship to synaptic receptors. Brain Res Rev 7:103-164.

Govitrapong P, Ebadi M (1988) The inhibition of pineal arylalkylamine $\mathrm{N}$-acetyltransferase by glutamic acid and its analogues. Neurochem Int 13:223-230.

Hayashi Y, Tanabe Y, Aramori I, Masu M, Shimamoto K, Ohfune Y, Nakanishi S (1992) Agonist analysis of 2-(carboxycyclopropyl)glycine isomers for cloned metabotropic glutamate receptor subtypes expressed in Chinese hamster ovary cells. Br J Pharmacol 107:539-543.

Hayashi Y, Momiyama A, Takahashi T, Ohishi H, Ogawa-Meguro R, Shigemoto R, Mizuno N, Nakanishi S (1993) Role of a metabotropic glutamate receptor in synaptic modulation in the accessory olfactory bulb. Nature 366:687-690.

Hayashi Y, Sekiyama N, Nakanishi S, Jane DE, Sunter DC, Birse EF, Udvarhelyi PM, Watkins JC (1994) Analysis of agonist and antagonist activities of phenylglycine derivatives for different cloned metabotropic glutamate receptor subtypes. J Neurosci 14:3370-3377.

Henquin J-C, Schmeer W, Meissner HS (1983) Forskolin, an activator of adenylate cyclase, increases $\mathrm{Ca}^{2+}$-dependent electrical activity induced by glucose in mouse pancreatic B cells. Endocrinology 112:2218-2220.

Inagaki N, Kuromi H, Gonoi T, Okamoto Y, Ishida H, Seino Y, Kaneko T, Iwanaga T, Seino S (1995) Expression and role of ionotropic glutamate receptors in pancreatic cells. FASEB J 9:686-691.

Klein DC (1985) Photoneural regulation of the mammalian pineal gland. In: Ciba Foundation Symposium 117: Photoperiodism, melatonin, and the pineal gland (Evered D, Clark S, eds), pp 38-56. London: Pitman.

Korf H-W Schomerus C, Maronde E, Stehle JH (1996) Signal transduction molecules in the rat pineal organ: $\mathrm{Ca}^{2+}, \mathrm{pCREB}$, and ICER Naturwissenshaften 83:535-543.

Kus L, Handa RJ, McNulty JA (1994) Glutamate inhibition of the adrenergic-stimulated production of melatonin in rat pineal gland in vitro. J Neurochem 62:2241-2245.

Mayer ML, Westbrook G (1987) The physiology of excitatory amino acids in the vertebrate central nervous system. Prog Neurobiol 28:197-276.

Meeker RB, Greenwood RS, Hayward JN (1994) Glutamate receptors in the rat hypothalamus and pituitary. Endocrinology 134:621-629.

Moriyama Y, Futai M (1990) $\mathrm{H}^{+}$-ATPase, a primary pump for accumulation of neurotransmitters, is a major constituent of brain synaptic vesicles. Biochem Biophys Res Commun 173:443-448.

Moriyama Y, Yamamoto A (1995a) Microvesicles isolated from bovine pineal gland specifically accumulate L-glutamate. FEBS Lett 367:233-236.

Moriyama Y, Yamamoto A (1995b) Vesicular L-glutamate transporter in microvesicles from bovine pineal glands: driving force, mechanism of chloride anion-activation, and substrate specificity. J Biol Chem 270:22314-22320.

Moriyama Y, Yamamoto A, Yamada H, Tashiro Y, Futai M (1996) Role of endocrine cell microvesicles in intercellular chemical transduction. Biol Chem 377:155-165.

Nakanishi S (1992) Molecular diversity of glutamate receptors and implications for brain function. Science 258:597-603.

Obata K, Nishiya H, Fujita SC, Shirao T, Inoue H, Uchizono K (1986) Identification of a synaptic vesicle-specific 38,000-dalton protein by monoclonal antibodies. Brain Res 375:37-45.

Okamoto N, Hori S, Akazawa C, Hayashi Y, Shigemoto R, Mizuno N, Nakanishi S (1994) Molecular characterization of a new metabotropic glutamate receptor mGluR7 coupled to inhibitory cyclic AMP signal transduction. J Biol Chem 269:1231-1236.
Pratt BL, Takahashi JS (1987) Alpha-2 adrenergic regulation of melatonin release in chick pineal cell cultures. J Neurosci 7:3665-3674.

Reiter RJ (1991) Pineal melatonin: cell biology of its synthesis and of its physiological interactions. Endocr Rev 12:151-180.

Riedel G (1996) Function of metabotropic glutamate receptors in learning and memory. Trends Neurosci 19:219-223.

Redecker P, Bargsten G (1993) Synaptophysin - a common constituent of presumptive secretory microvesicles in the mammalian pinealocyte: a study of rat and gerbil pineal glands. J Neurosci Res 34:79-96.

Roseboom PH, Coon SL, Baler R, McCune SK, Weller JL, Klein DC (1996) Melatonin synthesis: analysis of the more than 150-fold nocturnal increase in serotonin $N$-acetyltransferase messenger ribonucleic acid in the rat pineal gland. Endocrinology 137:3033-3044.

Rosen OM, Erlichman J, Rosen SM (1970) The structure-activity relationships of adrenergic compounds that act on the adenyl cyclase of the frog erythrocyte. Mol Pharmacol 6:524-531.

Sagara Y, Okatani Y, Yamanaka S, Kiriyama T (1988) Determination of plasma 5-hydroxytryptophan, 5-hydroxytryptamine, 5-hydroxyindoleacetic acid, tryptophan, and melatonin by HPLC with electrochemical detection. J Chromatogr 431:170-176.

Sambrook J, Fritsch EF, Maniatis T (1989) Molecular cloning: a laboratory manual, Ed 2. Cold Spring Harbor, NY: Cold Spring Harbor Laboratory.

Sekiyama N, Hayashi Y, Nakanishi S, Jane DE, Tse H-W, Birse EF, Watkins JC (1996) Structure-activity relationship of new agonists and antagonists of different metabotropic glutamate receptor subtypes. Br J Pharmacol 117:1493-1503.

Tanabe Y, Masu M, Ishii T, Shigemoto R, Nakanishi S (1992) A family of metabotropic glutamate receptors. Neuron 8:169-179.

Tanabe Y, Nomura A, Masu M, Shigemoto R, Mizuno N, Nakanishi S (1993) Signal transduction, pharmacological properties, and expression patterns of two rat metabotropic glutamate receptors, mGluR3 and mGluR4. J Neurosci 13:1372-1378.

Thomas KB, Zawilska J, Iuvone PM (1990) Arylalkylamine (serotonin) $N$-acetyltransferase assay using high-performance liquid chromatography with fluorescence or electrochemical detection of $\mathrm{N}$ acetyltryptamine. Anal Biochem 184:228-234.

Thomsen C, Kristensen P, Mulvihill E, Haldeman B, Suzdak PD (1992) L-2-amino-4-phosphonobutyrate (L-AP4) is an agonist at the type IV metabotropic glutamate receptor which is negatively coupled to adenylate cyclase. Eur J Pharmacol 227:361-362.

Tosini G, Menaker M (1996) Circadian rhythms in cultured mammalian retina. Science 272:419-421.

van Wyk E, Daya S (1994) Glutamate inhibits the isoprenaline-induced raise in melatonin synthesis by organ cultures of rat pineal glands. Med Sci Res 22:635-636.

Weaver CD, Yao TL, Powers AC, Verdoon TA (1996) Differential expression of glutamate receptor subtypes in rat pancreatic islets. J Biol Chem 271:12977-12984.

Yamada H, Yamamoto A, Yodozawa S, Kozaki S, Takahashi M, Michibata H, Morita M, Furuichi T, Mikoshiba K, and Moriyama Y (1996a) Microvesicle-mediated exocytosis of glutamate is a novel paracrine-like chemical transduction mechanism and inhibits melatonin secretion in pinealocytes. J Pineal Res 21:175-191.

Yamada H, Yamamoto A, Takahashi M, Michibata H, Kumon H, Moriyama Y (1996b) The L-type $\mathrm{Ca}^{2+}$ channel is involved in microvesicle-mediated glutamate exocytosis from rat pinealocytes. J Pineal Res 21:165-174.

Yamada H, Yatsushiro S, Yamamoto A, Nishi T, Futai M, Yamaguchi A, Moriyama Y (1997) Functional expression of GLT-1 type $\mathrm{Na}^{+}$dependent glutamate transporter in rat pinealocytes. J Neurochem 69:1491-1498.

Yatsushiro S, Yamada H, Kozaki S, Kumon H, Michibata H, Yamamoto A, Moriyama Y (1997) L-Aspartate but not the D form is secreted through microvesicle-mediated exocytosis and is sequestered through $\mathrm{Na}^{+}$-dependent transporter in rat pinealocytes. J Neurochem 69:340-347.

Zatz M, Mullen DA (1988) Norepinephrine, acting via adenylate cyclase, inhibits melatonin output but does not phase-shift the pacemaker in cultured chick pineal cells. Brain Res 450:137-143. 